\title{
The root extract of Paeonia lactiflora Pall inhibits the oxidative damage via its anti-oxidant activity
}

\author{
Ji Young Yun ${ }^{1 \#}$, Jin Boo Jeong ${ }^{1}$, Hyun Ji Eo ${ }^{1}$, Kun Woo Kwon ${ }^{1}$, Se Chul Hong ${ }^{2}$ \\ Hyung Jin Jeong ${ }^{1}$, Jin Suk Koo ${ }^{1 *}$
}

1 : Medicinal Plant Resources Major, Andong National University, Andong, 760749, Korea 2 : International Ginseng \& Herb Research Institute, Geumsan, 312804, Korea

\begin{abstract}
Objectives : Reactive oxygen species (ROS) have been associated with pathogenic processes including carcinogenesis through direct effect on DNA directly and by acting as a tumor promoter. Therefore, it has been regarded that ROS may be a major target for cancer prevention. The root of Paeonia lactiflora pall (PL), a traditional Chinese herb, has been a component of effective prescriptions for treatment of liver disease. Also, there are some reports about the antioxidant activities of the extracts from PL. However, little has been known about the effects of PL against oxidative damage. This work aimed to elucidate the anti-oxidant effects of Paeonia lactiflora pall (PL) in the non-cellular system and cellular system.

Methods : Antioxidant activities of PL were evaluated by hydroxyl radical scavenging assay and $\mathrm{Fe}^{2+}$ chelating assay. Anti-oxidative effect of PL was evaluated by $\varphi \mathrm{X}-174 \mathrm{RF}$ I plasmid DNA cleavage assay in non-cellular system. In addition, DNA migration assay, expression level of phospho-H2AX, MTT assay and lipid peroxidation assay were performed for evaluate the anti-oxidative effect of PL in cellular system.

Results : PL had a dose-dependent hydroxyl radical scavenging and $\mathrm{Fe}^{2+}$ chelating capacity. In addition, PL inhibited oxidative DNA and cell damage induced by hydroxyl radical in non-cellular system and cellular system.

Conclusion : Taken together, $P$. lactiflora pall may be possible for the application to a potential drug for treating the oxidative diseases such as cancer.
\end{abstract}

Key words : Anti-oxidant activity, Oxidative DNA damage, Oxidative cell damage, Paeonia lactiflora Pall

\section{Introduction}

Reactive oxygen species (ROS) have been associated with pathogenic processes including carcinogenesis through direct effect on DNA directly and by acting as a tumor promoter ${ }^{1)}$. Radicals have been demonstrated to be initiators of the oxidative process ${ }^{2)}$ and to be involved in the development of disease such as cancer $^{3)}$. Catalase, superoxide dismutase, glutathione and uric acid are examples of antioxidants produced by organisms under normal conditions as part of defense system against ROS-mediated cellular injury. However, if this defense system is challenged or overwhelmed by excessive generation of ROS, redox imbalance or oxidative stress may occur. This can result in damage to the organism and disease initiation ${ }^{4}$. ROS have also been shown to play an important role in carcinogenesis by damaging DNA and acting as tumor promoters ${ }^{1)}$. The health promoting effect of antioxidants from plants is thought to arise from their potential effects on the reactive oxygen/nitrogen species. In addition, antioxidants have been widely used in food industry to prolong the shelf life. However, there is widespread agreement that some synthetic antioxidants such as butylhydroxyanisole and butylhydroxytoluene need to be replaced with natural antioxidants due to

\footnotetext{
* Corresponding author : Jin Suk Koo, Medicinal Plant Resources Major, Andong National University, Andong, Korea. 760749.

· Tel : +82548205464 · Fax: +82548206252 ·E-mail : kimkoo1114@andong.ac.kr

\# First authors : Ji Young Yun, Medicinal Plant Resources Major, Andong National University, Andong, Korea. 760749.

• Tel: +82 548207753 •E-mail: boo56@hanmail.net

· 접수 : 2012년 9월 18일 · 수정 : 2012년 11월 3일 ·채택 : 2012년 11월 6일
} 
their potential health risks and toxicity ${ }^{5)}$.

Medicinal plants have been used to treat various human diseases in the East for centuries because of their good therapeutic performance and low toxicity). The use of traditional medicine is widespread and plants still represent a large source of natural antioxidants that might serve as leads for the development of novel drugs.

Paeonia lactiflora pall (PL) root, a traditional Chinese herb, has been a component of effective prescriptions for treatment of liver disease ${ }^{6)}$. Also, there are some reports about the antioxidant activities of the extracts from $\mathrm{PL}^{5)}$. However, little has been known about the functional role of PL against oxidative damage.

Therefore, it is important to understand the inhibitory mechanism of the extracts from PL against oxidative damage since these is a hallmark of many tumors and ROS-mediated signaling and genomic instability contributing to the initiation and progression of cancer

\section{Materials and Methods}

\section{Sample preparation}

Paeonia lactiflora pall (PL) root, a traditional Chinese herb, was kindly provided by the Bonghwa Alpine Medicinal Plant Experiment Station, Korea. One kilogram of the root of PL was extracted with $2 \mathrm{~L}$ of $80 \%$ methanol with shaking for 24 hours. After 24 hours, Extract with $80 \%$ methanol was filtered, concentrated to approximately $400 \mathrm{ml}$ volume using by a vacuum evaporator, and fractioned with ethyl acetate in a separating funnel. Aqueous fraction (32 g, yield rate: $3.2 \%$ ) after fractionation with ethyl acetate was freeze-dried and kept at $-70{ }^{\circ} \mathrm{C}$ until use.

\section{Hydroxyl radical scavenging activity}

Hydroxyl radical scavenger ability was measured according to a literature procedure ${ }^{7)}$ with a few modifications. Hydroxyl radical was generated from Fenton reaction between $1.5 \mathrm{mM} \mathrm{FeSO} 4$ and $6 \mathrm{mM} \mathrm{H} \mathrm{H}_{2}$ (1.4:1, v/v) at $37{ }^{\circ} \mathrm{C}$ for $30 \mathrm{~min}$ before the assay and detected by their ability to hydroxylate salicylate. The reaction mixture $(1 \mathrm{ml})$ contained $760 \mu l$ of hydroxyl radical, $40 \mu l$ of varying concentrations of the extracts (0.125, 0.25, 0.5, 1 and $2 \mathrm{mg} / \mathrm{ml})$ and $300 \mu l$ of sodium salicylate $(20 \mathrm{mM})$. After a reaction for $30 \mathrm{~min}$ at $37{ }^{\circ} \mathrm{C}$, the absorbance of the hydroxylated salicylate complex was measured at $562 \mathrm{~nm}$. Hydroxyl radical scavenger ability was calculated from the log-dose inhibition curve. All determination was carried out in triplicate. Ascorbic acid was used as a positive control.

\section{3. $\mathrm{Fe}^{2+}$ chelating activity}

This assay was measured according to a literature procedure $^{8)}$ with a few modifications. The reaction mixture $(800 \mu \ell)$ contained $120 \mu l$ of $2 \mathrm{mM} \mathrm{FeCl}_{2}, 40 \mu l$ of varying concentrations of the extracts $(0.125,0.25,0.5,1$ and 2 $\mathrm{mg} / \mathrm{ml}$ ) and $640 \mu \ell$ of distilled water. The mixture was shaken vigorously and left at room temperature for $5 \mathrm{~min}$. After $5 \mathrm{~min}, 200 \mu l$ of $5 \mathrm{mM}$ ferrozine was added and mixed. The absorbance of the $\mathrm{Fe}^{2+}$-ferrozine complex was measured at $562 \mathrm{~nm} . \mathrm{Fe}^{2+}$-chelating activity assay was calculated from the log-dose inhibition curve. All determination was carried out in triplicate. Deferoxamine was used as a positive control.

\section{4. $\varphi \mathrm{X}-174 \mathrm{RF}$ I plasmid DNA cleavage assay}

Conversion of the supercoiled form of plasmid DNA to the open-circular and further linear forms has been used as an index of DNA damage ${ }^{9)}$. For DNA cleavage assay by hydroxyl radical and ferrous iron, reaction mixtures $(90 \mu l)$ contained $10 \mu l$ of $\varphi$ $\mathrm{X}-174 \mathrm{RF}$ I plasmid DNA, $4 \mu \mathrm{u}$ of varying concentrations of the extracts $(0.25,0.5,1$ and 2 $\mathrm{mg} / \mathrm{ml}), 76 \mu l$ of hydroxyl radical generated from Fenton reaction between $250 \mu l$ of $1.5 \mathrm{mM} \mathrm{FeSO}_{4}$ and $175 \mu l$ of $6 \mathrm{mM} \mathrm{H} \mathrm{H}_{2}$. The mixtures were incubated at 37 oC for $30 \mathrm{~min}$. For DNA cleavage assay by ferrous iron, The mixtures contained $4 \mu l$ of varying concentrations of the extracts, $12 \mu l$ of $2 \mathrm{mM} \mathrm{FeCl}_{2}$, $64 \mu l$ of distilled water and $10 \mu l$ of $\varphi \mathrm{X}-174 \mathrm{RF}$ I plasmid DNA. The mixtures were incubated at $37 \mathrm{oC}$ for $30 \mathrm{~min}$. After the reaction for $30 \mathrm{~min}, 10 \mu \mathrm{l}$ of a solution containing 50\% glycerol (v/v), $40 \mathrm{mM}$ EDTA and $0.05 \%$ bromophenol blue was added to stop the reaction and the reaction mixtures was electrophoresed on $1 \%$ agarose gel. The DNA in the gel was visualized and photographed under ultraviolet light after ethidium bromide staining.

\section{Cell culture}

NIH 3T3 cell, mouse fibroblast cell line was purchased from the Korean Cell Line Bank (Seoul, Korea). Cell was cultured in Dulbeco' $\mathrm{s}$ modified Eagle' s medium (DMEM) containing $100 \mathrm{U} / \mathrm{ml}$ of penicillin, $100 \mathrm{lg} / \mathrm{ml}$ of streptomycin and 10\% fetal bovine serum. The cells were incubated in an atmosphere of $5 \% \mathrm{CO}_{2}$ at $37 \mathrm{oC}$. In all experiments, cells were grown to $80-90 \%$ confluence and subjected to no more than 20 cell passages.

\section{Intracellular DNA migration assay}

NIH3T3 cells $\left(2 \times 10^{6}\right)$ were cultured in 6-well 
plates for 24 hours at $37 \mathrm{oC}$ in an incubator with a humidified atmosphere of $5 \% \mathrm{CO}_{2}$. The cells were treated with the varying concentration of the extracts (0.5, 1 and $2 \mathrm{mg} / \mathrm{ml}$ ) for $30 \mathrm{~min}$ and then added with the total concentration of $1 \mathrm{mM} \mathrm{FeSO}_{4}$ and $1 \mathrm{mM}$ $\mathrm{H}_{2} \mathrm{O}_{2}$ for 24 hour. Each cell was harvested and after the centrifugation at $1250 \mathrm{rpm}$, the supernatant was discarded. Each cell was resuspended with 20 ul of lysis buffer (50 mM Tris-HCl, pH 8.0, $10 \mathrm{mM}$ EDTA, $0.5 \% \mathrm{SDS}$ and $0.5 \mathrm{mg} / \mathrm{ml}$ proteinase $\mathrm{K}$ ) by pipetting cells to ensure complete lysis and then incubated at $55{ }^{\circ} \mathrm{C}$ for $60 \mathrm{~min}$. After the centrifugation, $5 \mu l$ of RNase A was added to the supernatant and each cell was incubated at $55{ }^{\circ} \mathrm{C}$ for another $60 \mathrm{~min}$. After 60 min, each cell was spun briefly to remove any further cell debris and collect the supernatant. Each lysate was heated at $70{ }^{\circ} \mathrm{C}$ for a few minutes and mixed with $10 \mu l$ of loading buffer (50\% glycerol (v/v), 40 $\mathrm{mM}$ EDTA and $0.05 \%$ bromophenol blue). the reaction mixtures was electrophoresed on $2 \%$ agarose gel, and the DNA in the gel was visualized and photographed under ultraviolet light after ethidium bromide staining.

\section{Lipid peroxidation assay}

This assay was carried according to literature procedure $^{10)}$ with some modification. NIH3T3 cells were cultured in a 6 -well plate at $2 \times 10^{6}$ cells/well for 24 hours. Twenty four hours after plating, the cells treated with the varying concentrations of extract $(0.5,1$ and $2 \mathrm{mg} / \mathrm{ml}$ ) for $30 \mathrm{~min}$. After 30 min, the total concentration of $1 \mathrm{mM} \mathrm{H}_{2} \mathrm{O}_{2}$ and $1 \mathrm{mM}$ $\mathrm{FeSO}_{4}$ was added to the plate and incubated for 24 hours. The cells were then washed with cold phosphate-buffered saline (PBS), harvested, and homogenized in an ice-cold $1.15 \% \mathrm{KCl}$. One hundred microliters of the cell lysates was mixed with $0.1 \mathrm{ml}$ of $8.1 \%$ sodium dodecylsulfate, $0.75 \mathrm{ml}$ of $20 \%$ acetic acid (adjusted to $\mathrm{pH}$ 3.5), and $0.75 \mathrm{ml}$ of $0.8 \%$ thiobarbituric acid (TBA). The mixture was made up to a final volume of $4 \mathrm{ml}$ with distilled water and heated to $95 \mathrm{oC}$ for 2 hours. After cooling to room temperature, $2.5 \mathrm{ml}$ of an $\mathrm{n}$-butanol/pyridine mixture (15:1, v/v) was added and the mixture was shaken. After centrifugation at $1000 \mathrm{~g}$ for $10 \mathrm{~min}$, the supernatant fraction was isolated and the absorbance was measured spectrophotometrically at $532 \mathrm{~nm}$.

\section{MTT assay}

NIH3T3 cells $\left(5 \times 10^{3}\right.$ cells/well $)$ were cultured in 96-well plate at $37{ }^{\circ} \mathrm{C}$ for 24 hours. After 24 hours, the varying concentrations of the extracts $(0.5,1$ and
$2 \mathrm{mg} / \mathrm{ml}$ ) were treated to each well, and then incubated at $37{ }^{\circ} \mathrm{C}$ for $30 \mathrm{~min}$. After $30 \mathrm{~min}$, the total concentration of $1 \mathrm{mM} \mathrm{H}_{2} \mathrm{O}_{2}$ and $1 \mathrm{mM} \mathrm{FeSO}_{4}$ was applied to each well and then incubated at $37 \mathrm{oC}$ for 24 hours. After 24 hours, $50 \quad \mu l$ of MTT solution (1 $\mathrm{mg} / \mathrm{ml})$ was treated to each well for 4 hours, the supernatant was removed, and then $100 \mu l$ of DMSO was treated to each well. The observance was measured with a microplate reader at $570 \mathrm{~nm}$.

\section{Western blot of phospho-H2A.X}

NIH3T3 cells $\left(2 \times 10^{6}\right.$ cells/well $)$ were cultured in 6 -well plate at $37{ }^{\circ} \mathrm{C}$ for 24 hours. After 24 hours, the varying concentrations of the extracts $(0.5,1$ and $2 \mathrm{mg} / \mathrm{ml}$ ) were treated to each well, and then incubated at $37{ }^{\circ} \mathrm{C}$ for $30 \mathrm{~min}$. After $30 \mathrm{~min}$, the total concentration of $1 \mathrm{mM} \mathrm{H} \mathrm{H}_{2}$ and $1 \mathrm{mM} \mathrm{FeSO}_{4}$ was applied to each well and then incubated at $37 \mathrm{oC}$ for 24 hours. After 24 hours, each cell was harvested for the analysis. The cells were lysed with lysis buffer (50 $\mathrm{mM}$ Tris- $\mathrm{HCl} \mathrm{pH} 7.4,150 \mathrm{mM} \mathrm{NaCl}, 1 \mathrm{mM}$ EDTA, 1 $\mathrm{mM}$ EGTA, $10 \mu \mathrm{g} / \mathrm{ml}$ aprotinin, $10 \mu \mathrm{g} / \mathrm{ml}$ leupeptin, 5 $\mathrm{mM}$ phenylmethylsulfonyl fluoride [PMSF], and $1 \mathrm{mM}$ DTT) containing $1 \%$ Triton $\mathrm{X}-100$. Insoluble debris was removed by centrifugation at $15,000 \mathrm{~g}$ for $15 \mathrm{~min}$ three times. The protein extracted from the cells was separated on $15 \%$ Tris $-\mathrm{HCl}$ ready gel (Bio-rad, Hercules, CA) following the manufacturer' s instruction. Gels were transblotted on to PVDF membranes for western blot analysis. The membranes were blocked for non-specific binding for $90 \mathrm{~min}$ in block buffer $(5 \%$ non-fat milk and $0.1 \%$ Tween 20 in $1 \times$ Tris-buffered saline[TBS]) and then washed with $1 \times$ TBS solution (0.1\% Tween 20 in $1 \times$ TBS). After washing with $1 \times$ TBS solution, the membrane was incubated with phospho-H2A.X at 1:1000 dilutions in antibody dilution buffer ( $5 \%$ BSA, $1 \times$ TBS, $0.1 \%$ Tween 20 ) with gentle shaking at $4 \mathrm{oC}$ for 16 hours and then washed with $1 \times$ TBS solution. After washing, the membranes were incubated with Phototope-HRP Western Blot Detection System, Anti-rabbit IgG, HRP-linked Antibody as the secondary antibody at 1:1000 dilutions in antibody dilution buffer ( $5 \%$ non-fat milk and $0.1 \%$ Tween 20 in 1TBS) for $1 \mathrm{~h}$ and then washed again. After washing, the membranes were treated with the detection agent (Amersham Biosciences) and immediately developed in Polaroid film.

\section{Immuno-staining for phospho-H2A.X foci}

NIH3T3 cells $\left(5 \times 10^{4}\right)$ were cultured in 6-well plates with the cover glass for 24 hours at 37 oC. After 24 hours, the varying concentrations of water 
extract $(0.5$ and $2 \mathrm{mg} / \mathrm{ml})$ were treated to each well, and the cells were incubated at $37{ }^{\circ} \mathrm{C}$ for $30 \mathrm{~min}$. After $30 \mathrm{~min}$, the total concentrations of $1 \mathrm{mM} \mathrm{H} \mathrm{H}_{2} \mathrm{O}_{2}$ and $1 \mathrm{mM} \mathrm{FeSO}_{4}$ were applied to each well and the cells were incubated at $37{ }^{\circ} \mathrm{C}$ for 24 hours. After 24 hours, the cells were fixed with $2 \%$ formaldehyde for $30 \mathrm{~min}$ and then washed with $1 \times$ PBS for $5 \mathrm{~min}$ three times. PBS with $10 \%$ fetal bovine serum (PBS/FBS) was then added to block non-specific binding for an hour. After washing, anti phospho-H2A.X polyclonal anti-body was diluted in $0.1 \%$ saponin/PBS/FBS solution at 1:500 dilutions for an hour, and then washed with $1 \times$ PBS for $5 \mathrm{~min}$ three times. Subsequent antibody, Alexa-Flour 488 goat anti-rabbit IgG, and DAPI were used against phospho-H2A.X antibody and nuclei, respectively and the cells were incubated in the dark for an hour. Then, the cells were washed with $1 \times$ PBS and mounted with antifade mounting medium. Mounted slides were viewed under a fluorescence microscope using a $60 \times$ oil immersion objective. The excitation wavelengths for DAPI and phospho-H2A.X were $359 \mathrm{~nm}$ and $494 \mathrm{~nm}$, respectively.

\section{Statistical analysis}

All results were expressed as the mean \pm the standard deviation of triplicate analysis. Statistical analysis was performed with the Student' s unpaired t-test, with statistical significance set at *, $\mathrm{P}<0.05$.

\section{Results}

\section{Antioxidant activities of PL extract}

Antioxidant activities of ethyl acetate and aqueous fractions were evaluated by hydroxyl radical scavenging assay and $\mathrm{Fe}^{2+}$ chelating assay. In hydroxyl radical scavenging assay (Fig. 1A), aqueous fraction removed hydroxyl radical by $26 \%$ at $0.5 \mathrm{mg} / \mathrm{ml}, 84 \%$ at 1 $\mathrm{mg} / \mathrm{ml}$ and $93 \%$ at $2 \mathrm{mg} / \mathrm{ml}$. Ascorbic acid used as the positive control removed it by $57 \%$ at $0.125 \mathrm{mg} / \mathrm{ml}$, $93 \%$ at $0.25 \mathrm{mg} / \mathrm{ml}, 97 \%$ at $0.5 \mathrm{mg} / \mathrm{ml}$ and $1 \mathrm{mg} / \mathrm{ml}$, and $100 \%$ at $2 \mathrm{mg} / \mathrm{ml}$. Although hydroxyl radical scavenging activity of the extract was lower than that of ascorbic acid, it showed a strong $\mathrm{Fe}^{2+}$ chelating activity.

In $\mathrm{Fe}^{2+}$ chelating assay (Fig. 1B), aqueous fraction chelated $\mathrm{Fe}^{2+}$ ion by $87 \%$ at $0.125 \mathrm{mg} / \mathrm{ml}, 95 \%$ at 0.25 $\mathrm{mg} / \mathrm{ml}, 97 \%$ at $0.5 \mathrm{mg} / \mathrm{ml}$ and $1 \mathrm{mg} / \mathrm{ml}$ and $98 \%$ at 2 $\mathrm{mg} / \mathrm{ml}$. Deferoxamine used as the positive control chelated it by $37 \%$ at $0.125 \mathrm{mg} / \mathrm{ml}, 84 \%$ at 0.25 $\mathrm{mg} / \mathrm{ml}$ and $99 \%$ at $0.5 \mathrm{mg} / \mathrm{ml} \sim 2 \mathrm{mg} / \mathrm{ml}$.

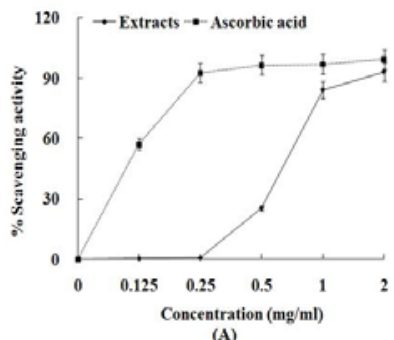

(A)

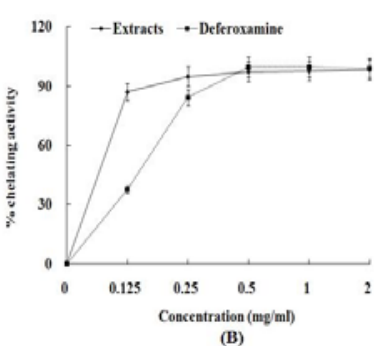

(B)
Fig. 1. Hydroxyl radical scavenging activity $(\mathrm{A})$ and $\mathrm{Fe}^{2+}$ chelating activity (B) of PL extract. The absorbance values were converted to scavenging activity or chelating activity (\%) and the data plotted as the mean of replicate scavenging effects or chelating effects (\%) values \pm 1 S.D. $(n=3)$ against extract concentration in $\mathrm{mg}$ extract per $\mathrm{ml}$ reaction volume. Ascorbic acid and deferoxamine were used as the positive control.

\section{Protective effect of PL extract against} oxidative damage in non-cellular system

The plasmid DNA cleavage assay using $\varphi \mathrm{X}-174 \mathrm{RF}$ I plasmid DNA was used as an initial approach toward determining whether aqueous fraction with antioxidant activity could inhibit oxidative DNA damage induced by hydroxyl radical or $\mathrm{Fe}^{2+}$ ion. Conversion of the supercoiled form (SC) of plasmid DNA to the open-circular form (OC) and further linear form (LC) has been used as an index of DNA damage ${ }^{9)}$.

It had no inhibitory effect on DNA damage induced by hydroxyl radical at the low concentrations $(0.25$ $\mathrm{mg} / \mathrm{ml}$ and $0.5 \mathrm{mg} / \mathrm{ml}$ ) while aqueous fraction (1 $\mathrm{mg} / \mathrm{ml}$ and $2 \mathrm{mg} / \mathrm{ml}$ ) inhibited DNA damage (Fig. 2A). But, aqueous fraction $(0.25 \mathrm{mg} / \mathrm{ml} \sim 2 \mathrm{mg} / \mathrm{ml})$ inhibited DNA damage induced by $\mathrm{Fe}^{2+}$ ion(Fig. 2B).

For the elucidation of the main mechanism for inhibitory effect on DNA damage at the low concentration $(0.5 \mathrm{mg} / \mathrm{ml})$ (Fig. $2 \mathrm{C}$ ), the treatments were divided into three groups. In the first group, water extract was reacted with hydroxyl radical and DNA together for $30 \mathrm{~min}$ at $37{ }^{\circ} \mathrm{C}$ (lane c). In the second group, it was firstly reacted with $\mathrm{Fe}^{2+}$ ion for $10 \mathrm{~min}$ at the room temperature and then re-reacted with $\mathrm{H}_{2} \mathrm{O}_{2}$ and DNA together for $30 \mathrm{~min}$ at $37{ }^{\circ} \mathrm{C}$ (lane $\mathrm{d}$ ). And in the third group, it was firstly reacted with $\mathrm{H}_{2} \mathrm{O}_{2}$ at $10 \mathrm{~min}$ at the room temperature and then re-reacted with $\mathrm{Fe}^{2+}$ ion and DNA together for $30 \mathrm{~min}$ at $37{ }^{\circ} \mathrm{C}$ (lane e). In this result, the simultaneous reaction of the extract with hydroxyl radical (lane c) and the pre-reaction with $\mathrm{H}_{2} \mathrm{O}_{2}$ (lane e) had no inhibitory effect on DNA damage, while the pre-reaction with $\mathrm{Fe}^{2+}$ ion inhibited the oxidative DNA damage by $90 \%$ (lane d). This result suggests that the extract may protect DNA from the oxidative damage by inhibiting the generation of hydroxyl radical through the blocking of Fenton reaction via $\mathrm{Fe}^{2+}$ ion chelation. 


\section{Protective effect of PL extract against oxidative damage in cellular system}

The inhibitory effect of the extract against oxidative DNA damage was evaluated by intracellular DNA migration and the expression level of phospho-H2A.X in the cellular system. DNA migration assay is a sensitive biomarker of the DNA damage. The extract inhibited DNA migration induced by hydroxyl radical in a dose-dependent manner (Fig. 3A). In the expression level of phospho-H2A.X, a sensitive marker for breaks of double stranded $\mathrm{DNA}^{11)}$, the treatment of the extract in presence of $\mathrm{H}_{2} \mathrm{O}_{2}$ and $\mathrm{FeSO}_{4}$ reduced the expression of phospho-H2A.X by $32 \%$ at $0.5 \mathrm{mg} / \mathrm{ml}, 53 \%$ at $1 \mathrm{mg} / \mathrm{ml}$ and $72 \%$ at 2 $\mathrm{mg} / \mathrm{ml}$, compared with the cells treated with $\mathrm{H}_{2} \mathrm{O}_{2}$ and $\mathrm{FeSO}_{4}$ in absence of the extract (Fig. 3B). This result was confirmed by changes of phospho-H2A.X foci into the nuclear in immuno-staining (Fig. 3C). Therefore, the results of the present study indicate that PL can inhibit the oxidative DNA damage induced by excessive ROS. Protective effect of the extract against oxidative cell damage was evaluated by MTT assay and lipid peroxidation assay. In MTT assay (Fig. 3D), hydroxyl radical generated from Fenton reaction between $\mathrm{H}_{2} \mathrm{O}_{2}$ and $\mathrm{FeSO}_{4}$ induced the oxidative cell death by $54 \%$, compared with the untreated cells. However, the treatment of water extract in presence of $\mathrm{H}_{2} \mathrm{O}_{2}$ and $\mathrm{FeSO}_{4}$ reduced the oxidative cell death, compared with the cell treated with $\mathrm{H}_{2} \mathrm{O}_{2}$ and $\mathrm{FeSO}_{4}$ in absence of the extract. It is thought that this result correlates with the inhibitory effect of the extract against lipid peroxidation. In the lipid peroxidation assay (Fig. 3E), the extract inhibited the lipid peroxidation by $39 \%$ at $0.5 \mathrm{mg} / \mathrm{ml}, 69 \%$ at 1 $\mathrm{mg} / \mathrm{ml}$ and $97 \%$ at $2 \mathrm{mg} / \mathrm{ml}$ compared with the cells treated with $\mathrm{H}_{2} \mathrm{O}_{2}$ and $\mathrm{FeSO}_{4}$. From this result, it is thought that the extract from PL displays a significant protective capability against the oxidative cell damage.

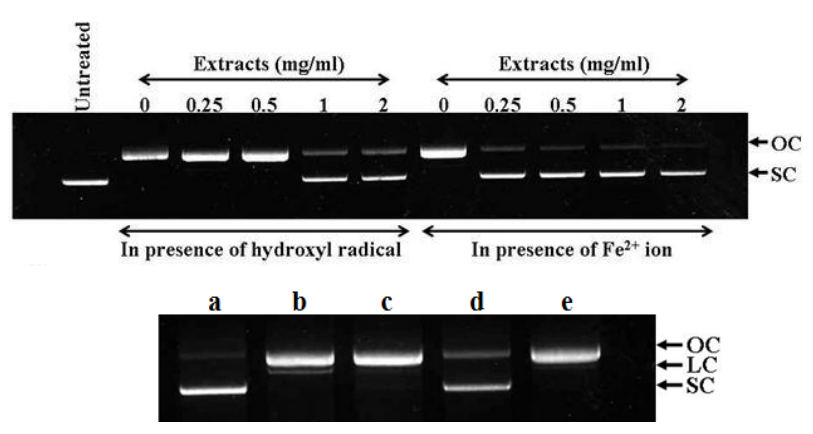

Fig. 2. Protective effect of $\mathrm{PL}$ extract against oxidative DNA damage in non-cellular system. (A) treatment of hydroxyl radical

in presence of aqueous fraction; (B) treatment of $\mathrm{Fe}^{2+}$ ion in presence of aqueous fraction; (C) Lane a was the normal DNA without hydroxyl radical and aqueous fraction. Lane $b$ was treated with hydroxyl radical alone without the aqueous fraction. In the lane $\mathrm{C}$, aqueous fraction was reacted with hydroxyl radical and DNA together for $30 \mathrm{~min}$ at $37{ }^{\circ} \mathrm{C}$. In the lane $\mathrm{d}$, aqueous fraction was firstly reacted with $\mathrm{Fe}^{2+}$ ion for $10 \mathrm{~min}$ at the room temperature, and then re-reacted with $\mathrm{H}_{2} \mathrm{O}_{2}$ and DNA together for $30 \mathrm{~min}$ at $37^{\circ} \mathrm{C}$. In the lane e, aqueous fraction was firstly reacted with $\mathrm{H}_{2} \mathrm{O}_{2}$ at $10 \mathrm{~min}$ at the room temperature, and then re-reacted with $\mathrm{Fe}^{2+}$ ion and DNA together for $30 \mathrm{~min}$ at $37^{\circ} \mathrm{C}$. In this assay, aqueous fraction was treated with $0.5 \mathrm{mg} / \mathrm{ml}$. In this assay, Hydroxyl radical was generated from Fenton reaction between $\mathrm{H}_{2} \mathrm{O}_{2}$ and $\mathrm{FeSO}_{4}$. Iron was generated from $\mathrm{FeCl}_{2}$.

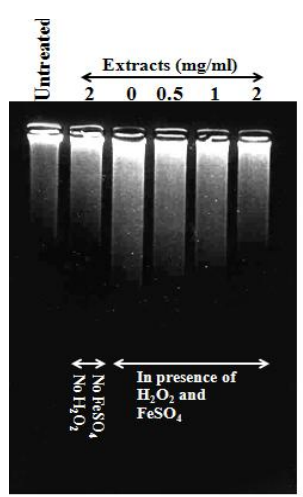

(A)

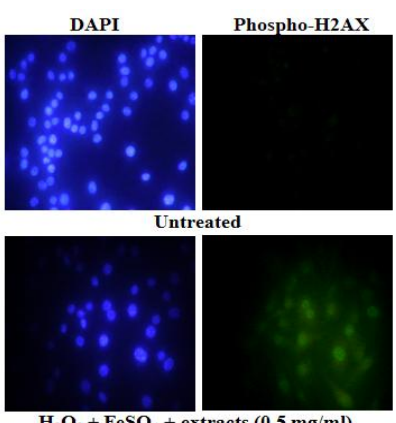

$\mathrm{H}_{2} \mathrm{O}_{2}+\mathrm{FeSO}_{4}+$ extracts $(0.5 \mathrm{mg} / \mathrm{ml})$

(C)

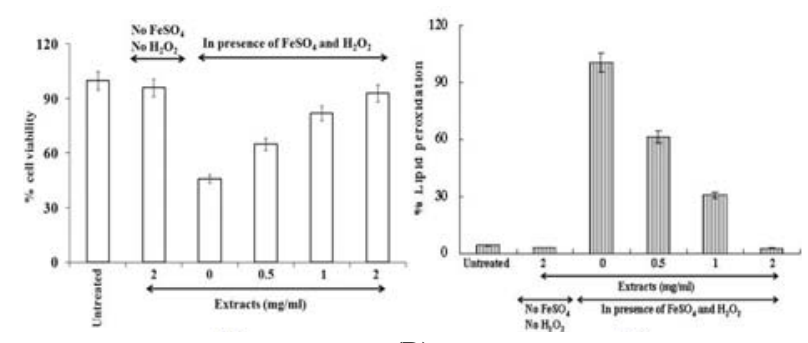

(D)

Fig. 3. Protective effect of PL extract against oxidative DNA and cell damage in the cellular system. The protective effect was evaluated by intracellular DNA migration assay (A), western blot for the level of phospho-H2AX expression (B), immuno-staining for the formation of phospho-H2AX foci (C), MTT assay (D) and lipid peroxidation assay (E). In western blot, each well was loaded with $25 \mu \mathrm{g}$ protein. \% ratio of the expression level of phospho-H2A.X was calculated by the density using the software Un-SCAN-IT gel Version 5.1 (Silk Scientific, Inc.). In MTT assay and lipid peroxidation assay, the absorbance values were converted to cell viability (\%) and inhibitory effects (\%), and the data plotted as the mean of replicate inhibitory effects (\%) values \pm 1 S.D. $(n=3)$. 


\section{Discussion}

Among ROS, hydroxyl radical is the most reactive and induces severe damage to adjacent biomolecules ${ }^{12)}$. Hydroxyl radical scavenging is an important antioxidant activity because of very high reactivity of hydroxyl radical which enables it to react with a wide range of molecules found in living cells such as sugars, amino acids, lipids and nucleotides ${ }^{13)}$. Iron is essential transition metal elements in the human body required for the activity of a large range of enzymes and for some proteins involved in cellular respiration, $\mathrm{O}_{2}$ transport and redox reactions. Unfortunately, they contain unpaired electrons that enable them to participate in one-electron transfer reactions. Hence, they are powerful catalysts of autoxidation reactions ${ }^{14)}$. Antioxidant factors can be divided into two groups such as scavenging of radicals formed during reaction and inhibiting the radical generation. From these results, its hydroxyl radical scavenging activity demonstrates the effectiveness against biologically generated radicals. Moreover, its $\mathrm{Fe}^{2+}$ chelating activity demonstrates the effectiveness for inhibiting the radical generation. Therefore, it suggests that PL extract can reduce ROS damage by scavenging the generated radical and inhibiting the radical generation.

The most important target for ROS in the carcinogenesis process is $\mathrm{DNA}^{15)}$. When present in a high enough concentration, these compounds can damage cellular proteins and DNA, or form DNA adducts that may promote carcinogenic activity ${ }^{16)}$. This DNA damage induced by hydroxyl radical has been shown to play a key role in the carcinogenesis ${ }^{17)}$. In addition, a possible mechanism of oxidative DNA damage induced by metals is thought to be the formation of hydroxyl radicals through Fenton-type reduction with hydrogen peroxide, which is naturally present in cells ${ }^{18)}$. Therefore, the inhibition of oxidative DNA damage is important to a chemoprevention of the carcinogenesis. In this study, we found that PL extract protected oxidative DNA damage in non-cellular and cellular system.

ROS damage involves injury to cellular membranes. Measurement of lipid peroxidation is used as an indicator or membrane damage in mammalian cells, resulting in the oxidative cell death. Lipid peroxidation can cause a cascade effect of lipid-derived radicals, thereby causing additional membrane damage. The products of lipid peroxidation, malondialdehyde and other group of aldehyde products may also cause DNA damage. It has also been proposed that free radicals derived from lipid peroxidation may be an important cause of cell membrane destruction and cell damage and function as tumor initiator ${ }^{19)}$. In this study, we found that PL extract protected oxidative cell damage in cellular system.

\section{Conclusion}

In summary, the results of the present investigation indicate the below.

1. Aqueous fraction from PL scavenged hydroxyl radical and chelated $\mathrm{Fe}^{2+}$ ion

2. Oxidative DNA damage from hydroxyl radical produced by fenton reaction was inhibited by aqueous fraction from PL

3. Oxidative cell damage induced by exposure to hydroxyl radical was inhibited by aqueous fraction from PL.

In conclusion, these inhibitory effects on oxidative damage via its antioxidant activity may further explain that Paeonia lactiflora pall may be possible for the application to a potential drug for treating the oxidative diseases such as cancer.

\section{Acknowledgement}

This work was supported by a support work for Andong Agricultural Technology Center (2008) and by Basic Science Research Program through the National Research Foundation of Korea (NRF) funded by the Ministry of Education, Science and Technology (2011-0013786).

\section{References}

1. Kong AN, Yu R, Hebbar V, Chen C, Owuor E, Hu R, Ee R, Mandlekar S. Signal transduction events elicited by cancer prevention compounds. Mutat Res. 2001 ; 480-481 : 231-41.

2. Pietraforte D, Turco L, Azzini E, Minetti M. On-line EPR study of free radicals induced by peroxidase/H2O2inhumanlow-densitylipoprotein.Bioc himBiophysActa. 2002;1583(2):176-84.

3. Stohs SJ. The role of free radicals in toxicity and disease. J Basic Clin Physiol Pharmacol. 1995 ; 6 : 205-28.

4. Halliwell B, Gutteridge JMC. Free Radicals in Biology and Medicine, Oxford University Press, Oxford, UK, 2rd edition, 1989.

5. Li HB, Wong CC, Cheng KW, Chen F. Antioxidant properties in vitro and total phenolic contents in methanol extracts from medicinal plants. LWT - 
Food Sci Technol. 2008 ; 41 : 385-90.

6. Dai LM, Chen MZ, Xu SY. Protective effects of total glucocides of paeony on experimental hepatitis. Zhongguo Yaolixue Tongbao. 1993 ; 9 : 449-53.

7. Smirnoff N, Cumbes QJ. Hydroxyl radical scavenging activity of compatible solutes. Phytochemistry. $1989 ; 28: 1057-60$.

8. Hus B, Coupar IM, Ng K. Antioxidant activity of hot water extract from the fruit of the Doum palm. Hyphaene thebaica. Food Chem. 2006 ; 98 : $317-28$.

9. Jung Y, Surh Y. Oxidative DNA damage and cytotoxicity unduced by copper-stimulated redox cycling of salsolinol, a neurotoxic tetrahydroisoquinoline alkaloid. Free Radical Biol Med. 2001 ; 30(12) : 1407-17.

10. Kang KA, Zhang R, Piao MJ, Ko DO, Wang ZH, Kim BJ, Park JW, Kim HS, Kim DH, Hyun JW. Protective effect of irisolidone, a metabolite of kakkalide, against hydrogen peroxide induced cell damage via antioxidant effect. Bioorgan Med Chem. $2008 ; 16: 1133-41$.

11. Rogakou EP, Pilch DR, Orr AH, Ivanova VS, Bonner WM. DNA double-stranded breaks induce histone H2AX phosphorylation on serine 139. J Biol Chem. 1988 ; 273 : 5858-68.

12. Sakanaka S, Tachibana Y, Okada Y. Preparation and antioxidant properties of extracts of Japanese persimmon leaf tea (kakinoha-cha). Food Chem. $2005 ; 89: 569-75$.

13. Stohs SJ, Bagchi D. Oxidative mechanism in the toxicity of metal ions. Free Radical Biol Med. 1995 ; $18: 321-36$.

14. Lloyd RV, Hanna PM, Mason RP. The origin of the hydroxyl radical oxygen in the Fenton reaction. Free Radical Bio Med. 1997 ; 22 : 885-88.

15. Lopaczynski W, Zeisel SH. Antioxidants, programmed cell death, and cancer. Nutr Res. 2001 ; 21 : 295-307.

16. Seifried HE, Anderson DE, Fisher EV, Milner JA. A review of the interaction amone dietary antioxidants and reactive oxygen species. J Nutr Biochem. 2007 ; 28 : 567-79.

17. Barreto R, Kawakita S, Tsuchiya J, Minelli E, Pavasuthipasit K, Helmy A, Marotta F. Metal-induced oxidative damage in cultured hepatocytes and hepatic lysosomal fraction: beneficial effect of a curcumin/absinthium compound. Chin J Dig Dis. $2005 ; 6: 31-6$.

18. Moriwaki H, Osborne MR, Phillips DH. Effect of mixing ions on oxidative DNA damage mediated by a Fenton-type reduction. Toxicol in Vitro. 2008 ; 22 : 36-44.
19. Yoshikawa T, Naito Y, Kondo M. Food and disease. In: Free radicals and diseases. New York : Plenum press. 1997 : 11-9. 